\title{
Roadless and Low-Traffic Areas as Conservation Targets in Europe
}

\author{
Nuria Selva • Stefan Kreft • Vassiliki Kati • \\ Martin Schluck • Bengt-Gunnar Jonsson • \\ Barbara Mihok $\cdot$ Henryk Okarma $\cdot$ Pierre L. Ibisch
}

Received: 23 April 2010/Accepted: 31 August 2011/Published online: 24 September 2011

(C) The Author(s) 2011. This article is published with open access at Springerlink.com

\begin{abstract}
With increasing road encroachment, habitat fragmentation by transport infrastructures has been a serious threat for European biodiversity. Areas with no roads or little traffic ("roadless and low-traffic areas") represent relatively undisturbed natural habitats and functioning ecosystems. They provide many benefits for biodiversity and human societies (e.g., landscape connectivity, barrier against pests and invasions, ecosystem services). Roadless
\end{abstract}

Electronic supplementary material The online version of this article (doi:10.1007/s00267-011-9751-z) contains supplementary material, which is available to authorized users.

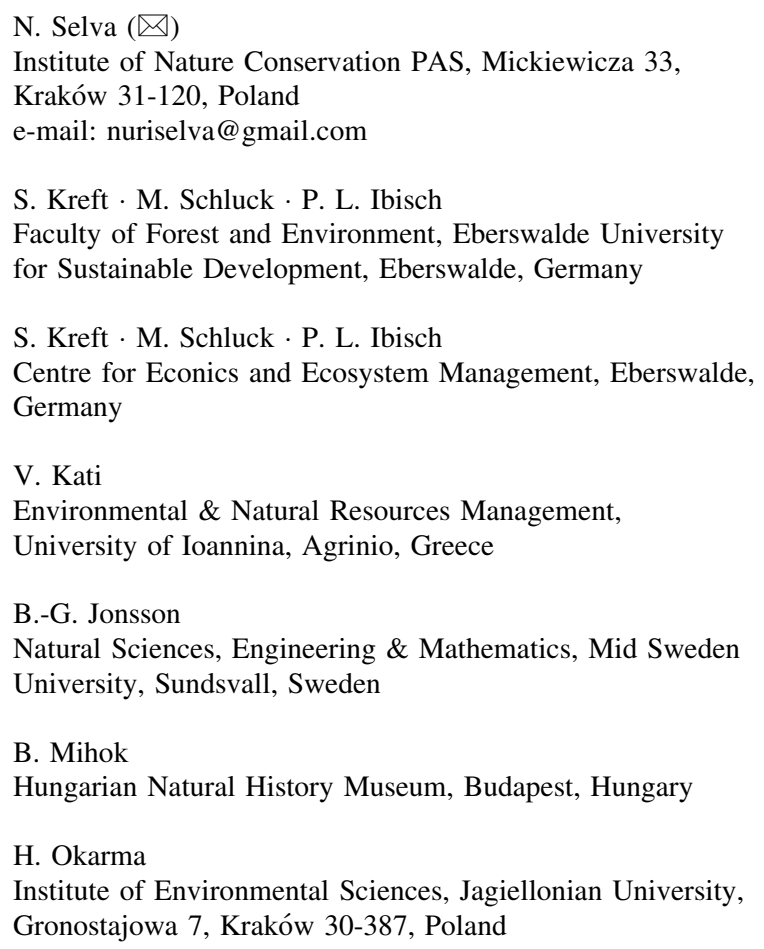
and low-traffic areas, with a lower level of anthropogenic disturbances, are of special relevance in Europe because of their rarity and, in the context of climate change, because of their contribution to higher resilience and buffering capacity within landscape ecosystems. An analysis of European legal instruments illustrates that, although most laws aimed at protecting targets which are inherent to fragmentation, like connectivity, ecosystem processes or integrity, roadless areas are widely neglected as a legal target. A case study in Germany underlines this finding. Although the Natura 2000 network covers a significant proportion of the country (16\%), Natura 2000 sites are highly fragmented and most low-traffic areas (75\%) lie unprotected outside this network. This proportion is even higher for the old Federal States (western Germany), where only 20\% of the low-traffic areas are protected. We propose that the few remaining roadless and low-traffic areas in Europe should be an important focus of conservation efforts; they should be urgently inventoried, included more explicitly in the law and accounted for in transport and urban planning. Considering them as complementary conservation targets would represent a concrete step towards the strengthening and adaptation of the Natura 2000 network to climate change.

Keywords Transport policy - Natura 2000 .

Fragmentation - Conservation law · Conservation targets . Climate change adaptation

\section{Introduction}

Habitat fragmentation by transport networks and consequential secondary development has become one of the most serious global threats to biological diversity (EEA 2002; Iuell and others 2003; Laurance and others 2009; 
Benítez-López and others 2010). With more than 100 million $\mathrm{km}$ of roads worldwide (CIA 2008), the road network plays a main role in shaping the environment. Road effects have been widely studied and include biodiversity decline, environmental degradation, alteration of ecological processes and ecosystem services, and increases in both extinction and outbreak probabilities (Forman and Alexander 1998; Trombulak and Frissell 2000; Forman and others 2003; Fahrig and Rytwinski 2009). By acting as a barrier, roads isolate populations, reduce the overall landscape connectivity and restrict (or even block off) gene flow for a wide variety of taxa (Keller and others 2004; Epps and others 2005; Riley and others 2006; Balkenhol and Waits 2009). In a long term, this loss of genetic diversity and connectivity increases the extinction risk of populations and, reduces their ability to adapt to future global changes. In general, these effects are synergistic, extremely complex, cumulative and time-lagged (Forman and Alexander 1998; Findlay and Bourdages 2000; McGarigal and others 2001; Forman and others 2003).

The spatial influence of these effects ("road-effect zone") ranges from a few meters to kilometres (e.g., Forman and Deblinger 2000). When taking into account this road area-of-influence, about one fifth of the land in USA and the Netherlands is ecologically affected by the road system (Reijnen and others 1995; Forman 2000). Estimates indicate that only $18 \%$ of the USA lands are more than $1 \mathrm{~km}$ away from the closest road (Riitters and Wickham 2003). Not only major roads, but also minor and unpaved roads may have a considerable impact on the environment (e.g., van Langevelde and others 2009). This may be especially true when crossing natural habitats. Natural areas are being increasingly fragmented by a rapidly expanding transport network, together with urban sprawl (EEA 2006, 2010). In the case of USA forests, estimations yield about $11 \%$ of all forest located within $85 \mathrm{~m}$ of a road (Riitters and Wickham 2003).

The secondary impacts of roads account for an even more serious threat to biodiversity and ecosystem resilience. Land use and transport networks are interdependent in complex ways (Wilkie and others 2000; EEA 2006; Müller and others 2010). Roads facilitate human access into formerly remote areas, accelerating land use change, habitat degradation and biodiversity loss, due to an increase in hunting, poaching, fishing, tourism, logging, mining, fires and urbanization (Trombulak and Frissell 2000; Wilkie and others 2000; Hawbaker and others 2006). Urban development and sprawl are strongly linked to transport networks, also in rural and natural environments (Wilkie and others 2000; EEA 2006; Müller and others 2010). Thus, the density of transport infrastructures is a good indicator of the intensity of human activities and their impacts on biological diversity, and can be taken as a proxy for general disturbance levels (e.g., Wilkie and others 2000; Sanderson and others 2002; Hawbaker and others 2006; Theobald 2008; Laurance and others 2009). Anthropogenic disturbances, in general, cause stress and reduce resilience and adaptive capacity of populations and species. This is of special concern in the context of climate change, which is increasing local extinction rates and forcing latitudinal and elevational shifts in species ranges (Walther and others 2002; Parmesan 2006).

Europe, as the cradle of industrialization and vehicular transport, is probably the continent most highly fragmented by transport infrastructures. Especially the EU-12 countries (Austria, Belgium, Denmark, Finland, France, Germany, Ireland, Italy, Luxembourg, Netherlands, Sweden, United Kingdom), historically highly developed and crowded, constitute the epicenter of habitat conversion and fragmentation (Pullin and others 2009). The quality of road data is inconsistent across Europe. It would be informative, for example, to differentiate between urban and rural roads, as well as among road types (motorways, highways, minor roads). However, such specific data are available only regionally or even locally. Taking into account these constraints, the following examples convincingly highlight the issue raised in this paper. The total length of roads belonging to the "Trans-European Transport Network" (TENT-T, a subset of the continent's overall road network targeted to support the economical integration of the EU) in 2005 was $98,500 \mathrm{~km}$, of which $78 \%$ corresponded to roads in EU-15 countries (EU-12 plus Greece, Portugal, Spain, data from TINA 2008). In a 10-year period (1995-2005) the length of "motorways" has increased by more than $13,000 \mathrm{~km}$ in the EU countries (Steer Davies Gleave 2009). While EU plans imply slight increases of its total length, planned upgradings would increase the proportion of "motorways" in the network from 49\% (2005) to 63\% (2020). The land dedicated to transport networks continues to increase in the whole EU. In the period 1990-1998 approximately 10 ha of land were taken for new motorway construction every day in the EU-15 (EEA 2002). For example, in the Netherlands, on average $1 \mathrm{~km}^{2}$ of land is crossed by $3 \mathrm{~km}$ of asphalt road (EEA 2002); and the average size of polygons enclosed by the network of all roads is $1.14 \mathrm{~km}^{2}$ (van Langevelde and others 2009). In Belgium, transport infrastructure already occupies more than $4 \%$ of the country's surface area (EEA 2002).

The environmental consequences of this process may be different in the already highly fragmented EU-15 and in the New Member States (accessions from 2004; Bulgaria, Cyprus, Czech Republic, Estonia, Hungary, Latvia, Lithuania, Malta, Poland, Romania, Slovakia, Slovenia, EU-27) with a lower density of roads and generally harbouring relatively well-preserved biodiversity and ecosystems, but 
where transport infrastructures are developing quickly after their accession. Fragmentation by transport infrastructures in Hungary and in the Czech and Slovak Republics are already more severe than the EU-15 average. In the 1990s, total motorway length doubled in the New Members ( $2300 \mathrm{~km}$ built), while in the EU-15 it increased by almost one third (12000 km built, EEA 2002). The average size of contiguous land units not cut through by "major" transport infrastructures in the New Members $\left(174 \mathrm{~km}^{2}\right.$, EEA 2002, data from 1998) is still above the average of the EU-15 $\left(121 \mathrm{~km}^{2}\right)$. However, differences between individual EU Member States are more pronounced; Finland, and Scandinavian countries in general, being the least fragmented in the continent, followed by countries in the Carpathian region. Mountainous countries, like Italy or Austria, still maintain relatively large unfragmented patches (EEA 2002).

Thus, it seems reasonable to hypothesize that the few areas of low or no road fragmentation still existing in Europe might be an important focus of future conservation efforts. In this paper, the term "roadless areas" refers to relatively large areas without any roads, whereas areas containing only roads with low-traffic intensity, below an established limit, are termed "low-traffic areas" (see definition below). Our main goal is to bring attention to the conservation value of roadless and low-traffic areas in Europe, specifically in the EU. We aim at (1) describing the benefits of roadless and low-traffic areas for biodiversity conservation; (2) exploring how these areas are valued and considered in European legislation; (3) assessing how lowtraffic areas are protected as Natura 2000 sites in Germany, as a case study, comparing the western and eastern parts of the country; and, (4) discussing the potential role of roadless and low-traffic areas to strengthen the effectiveness of the Natura 2000 network, especially in the context of climate change and the unaccomplished goal of halting biodiversity loss by 2010 (EU 2001; EC 2010), as well as their integration into legal instruments and transport policies.

\section{Importance of Roadless and Low-Traffic Areas in Biodiversity Conservation}

Roadless areas and, to a lesser extent, low-traffic areas, represent relatively undisturbed natural habitats and functioning ecosystems. As at low traffic intensity, road impacts, such as the barrier effect for fauna, wildlife disturbance or pollution, are dampened (Iuell and others 2003; Jaeger and others 2006; Theobald 2008; Charry and Jones 2009), it is sensible to assume that low-traffic areas may also represent sites of high conservation value, especially in Europe, a human-dominated landscape. Under this scenario, the ecological benefits described for roadless areas, which have been the focus of most research, may well apply to low-traffic areas as well.

Scientific evidence shows that roadless areas are critical in maintaining biodiversity, ecosystem processes, connectivity and overall ecosystem integrity. Large, wellconnected patches increase landscape connectivity and complement the network of protected areas (e.g., DeVelice and Martin 2001; Loucks and others 2003; Crist and others 2005). Thus, roadless areas sustain important elements of ecosystem integrity, such as the ability of species to move and natural processes to function. They largely contribute to the preservation of native biodiversity and contain more species and individuals, species with large spatial requirements (e.g., top carnivores), and species sensitive to human disturbance (Haskell 2000; Watkins and others 2003; Angelstam and others 2004; Blake and others 2008; Chen and Roberts 2008). They have the potential to ensure sufficient habitat for viable populations of species of conservation concern, as well as to increase the representation of rare ecological communities (Strittholt and DellaSala 2001; Loucks and others 2003; Crist and others 2005). They serve as a barrier against pests, diseases (of wildlife, livestock and humans, e.g., the Lyme disease) and invasive species (Strittholt and DellaSala 2001; Allan and others 2003; Gelbard and Harrison 2003; Holdsworth and others 2007; von der Lippe and Kowarik 2007). They ensure crop pollination, air quality, water supply and erosion control. It is in these large areas of unfragmented land that ecosystem services, vital for human societies, are rendered (Millennium Ecosystem Assessment 2005).

Roadless and low-traffic areas are of special importance in the context of climate change because they are more resilient than areas more fragmented by roads, and because they have a vast buffering capacity (McGarigal and others 2001). Their ecosystem dynamics are still internally driven, as opposite to the dynamics of fragmented patches, which are predominantly driven by external forces (Saunders and others 1991). Ecosystems already fragmented and stressed by human activities will be more vulnerable to climatic threats, while large intact areas better resist and recover from climate change impacts (Markham 1996; Laurance and Williamson 2001; Noss 2001; Opdam and Wascher 2004; Ferguson and others 2008). These relatively undisturbed habitat patches can facilitate movements of organisms in the case of climate-forced range shifting. In general, they may represent "havens" for many species that are displaced from former habitats (Noss 2001; Lovejoy 2006). By slowing the rates of changes, moderating local climate, and being more diverse and resilient, roadless and low-traffic areas may contribute to mitigate the effects of species phenology changes and trophic 
mismatches caused by climate change (Parmesan 2006), and to facilitate species adaptation.

Especially when comprising forest ecosystems or peatlands, roadless and low-traffic areas can play an important role in carbon fixation. Undisturbed habitats may be better players in carbon sequestration than their fragmented and degraded counterparts (Harmon and others 1990; Laurance and Williamson 2001; Ferguson and others 2008; Luyssaert and others 2008). It should be a relevant hypothesis to test that relatively carbon-rich ecosystem types in roadless and low-traffic areas store more carbon for maintaining a less stressed and thus more functional status. In the case of forests, in areas with poor access (e.g., in remote mountain areas), the amount of deadwood and soil carbon should be higher. Roadless and low-traffic areas also provide protection against the impacts of storm events, like flooding or landslides, and wildfires (lower fire risk and higher resilience; USDA Forest Service 2000, 2001; DellaSala and Frost 2001; Laurance and Williamson 2001; Ferguson and others 2008). These relatively intact areas contribute to floodplain protection and drought abatement, as well as to maintain local climates stables and buffering weather extremes. The social and economic benefits of roadless and low-traffic areas, such as recreation, have also been well documented (Noss 1991; Loomis and Richardson 2000; Krieger 2001).

\section{Roadless and Low-Traffic Areas in the European Legislation}

Roadless and low-traffic areas, as lands with a relatively low human footprint and good conservation status, have been considered a priority in regional conservation planning in several countries outside Europe. For example, in Bolivia, various conservation planning exercises on regional and national scales followed a functional approach and integrated roadless areas as surrogates for functional conservation targets, such as ecosystem processes and emergent features of biodiversity, especially required in the face of environmental change (viability, resilience and adaptive capacity; Ibisch and others 2005). However, the most ground-breaking initiative and important precedent has been the U.S. Roadless Area Conservation Rule of 2001. It stated that $237,000 \mathrm{~km}^{2}$ within the U.S. National Forest System ( $2 \%$ of US continental land) will remain roadless and protected from most forms of timber extraction. The two inventories of roadless areas, RARE I and RARE II, included unfragmented patches larger than 2024 ha (an important part of which was designated as Wilderness) and 405 ha, respectively (see USDA Forest Service 2001; Strittholt and DellaSala 2001; Turner 2006, 2009 for details).
In Europe, initiatives specifically restricting road development in natural areas and giving special attention to the protection of roadless and low-traffic areas have hardly been launched. The centerpiece of the EU nature conservation policy is the Natura 2000 network, which consists of Special Protection Areas and Special Areas of Conservation delineated according to the provisions of the Birds and Habitats Directives, respectively (79/409/ EEC and 92/43/EEC, see Pullin and others 2009). Although both European Directives oblige the Member States to take the appropriate measures to maintain the integrity of Natura 2000 sites and to guarantee the longterm persistence of species and ecosystems, in practice they face enormous difficulties in avoiding habitat fragmentation. Very illustrative are recent conflicts like the planned construction of the Via Baltica express-way through the Biebrza marshes, the unique Rospuda mire and two large natural forests in northeastern Poland (EEA 2006). Moreover, a high proportion of Natura 2000 sites is already in close proximity to major transport infrastructures and/or will be potentially affected by the future development of the European transport network (Fisher and Waliczky 2001; EEA 2002).

We conducted an exploration of European legal instruments, ranging from selected national laws to EU nature conservation directives and European conventions (Table 1, see supplementary material (Appendix) for detailed description of the laws). Only one of the explored laws considered roadless or low-traffic areas as a conservation target, although, paradoxically, the majority of them aimed at protecting other targets which are inherently and intimately related to fragmentation like connectivity, ecosystem processes or integrity. One important finding is an apparent conceptual shift from mere species and habitat protection (e.g., Bern Convention 1979) to more holistic approaches of ecosystem conservation, including processes, functions and aspects of integrity. We especially consider the Carpathian Convention (2003) that explicitly addresses regulations of traffic impacts and development, and encourages the parties to develop sustainable transport policies. Only very recently, Germany established that "traffic and energy infrastructure and similar projects shall be integrated so that fragmentation and consumption of the landscape as well as ecological impairment is avoided or reduced to a minimum" (Federal Nature Conservation Act from 29 July 2009; Table 1). In spite of the apparent trend that European nature legislation is starting to consider minimising fragmentation by transport infrastructures, it is unfortunate that neither the EU nor the large majority of national laws recognise the significance of areas with low levels of fragmentation by roads in their conservation policies. 


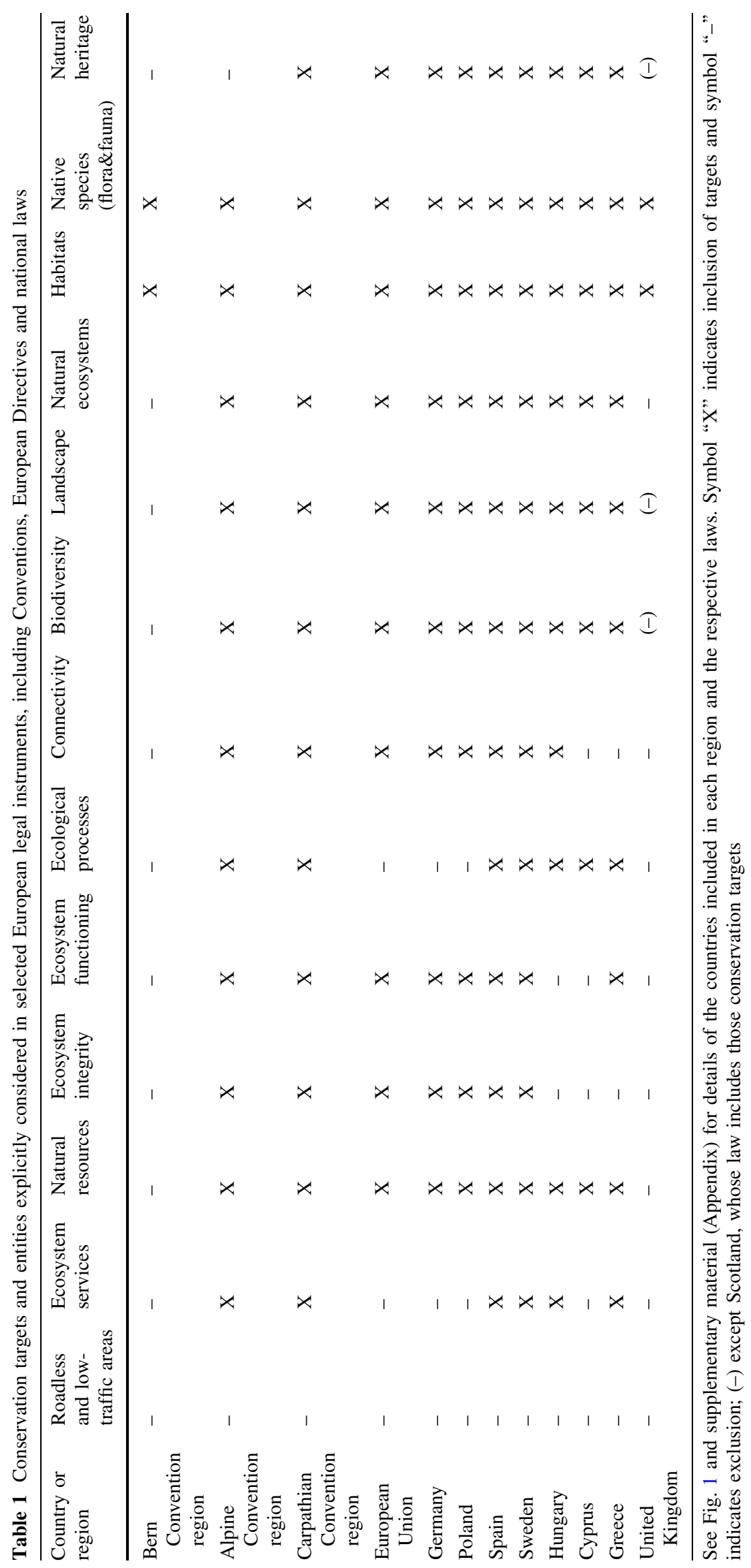




\section{Roadless and Low-Traffic Areas and Natura 2000: Germany as a Case Study}

Germany is one of the largest European countries, located in the center of the continent, including a wide variety of biogeographical regions. It particularly exemplifies different situations in European nature conservation. After World War II, Germany was divided into the Federal Republic of Germany (western Germany) and the German Democratic Republic (eastern Germany); in 1990 they were unified again. Differences in natural conditions, history, political regimes, social models and economic development between eastern and western Germany illustrate well the differences between the so-called "western" and "eastern Europe," once separated by the Iron Curtain. Germany lies in the transition zone between these two parts of Europe (Fig. 1). It reflects somehow different situations between the highly developed and industrialized countries in EU-15 and the New Member States, more rural and less fragmented by transport infrastructures. These two German regions also show strong differences in population density; the "old"
Federal States (former Federal Republic of Germany) have almost twice the population density of the "new" Federal States (former German Democratic Republic).

Germany is the first European country where data on the distribution and size of low-traffic areas have become available. The German Federal Agency for Nature Conservation conducted a first inventory of large areas not cut by major transport infrastructures (BfN 2008), whose data were used for the present study (Federal Agency for Nature Conservation, technical data on Natura 2000 from 2008, unpublished). These low-traffic areas were defined as larger than $100 \mathrm{~km}^{2}$ and not dissected by roads with more than 1000 vehicles per day, by railway lines (twin-track and single-track electrified lines) or by human settlements, airports or channels (with the status of a Category IV Federal waterway or above). These criteria are generally applied in Europe (e.g., Andel and others 2005; Jaeger and others 2007; BfN 2008). Although further research to identify threshold values for traffic volumes are needed, the value of 1000 vehicles per day seems to be an acceptable synthesis of the current ecological evidence and models
Fig. 1 Map of Europe indicating the members of the European Union (with a distinction of the New Member States that have acceded since 2004) and the contracting parties under the Alpine and Carpathian Convention
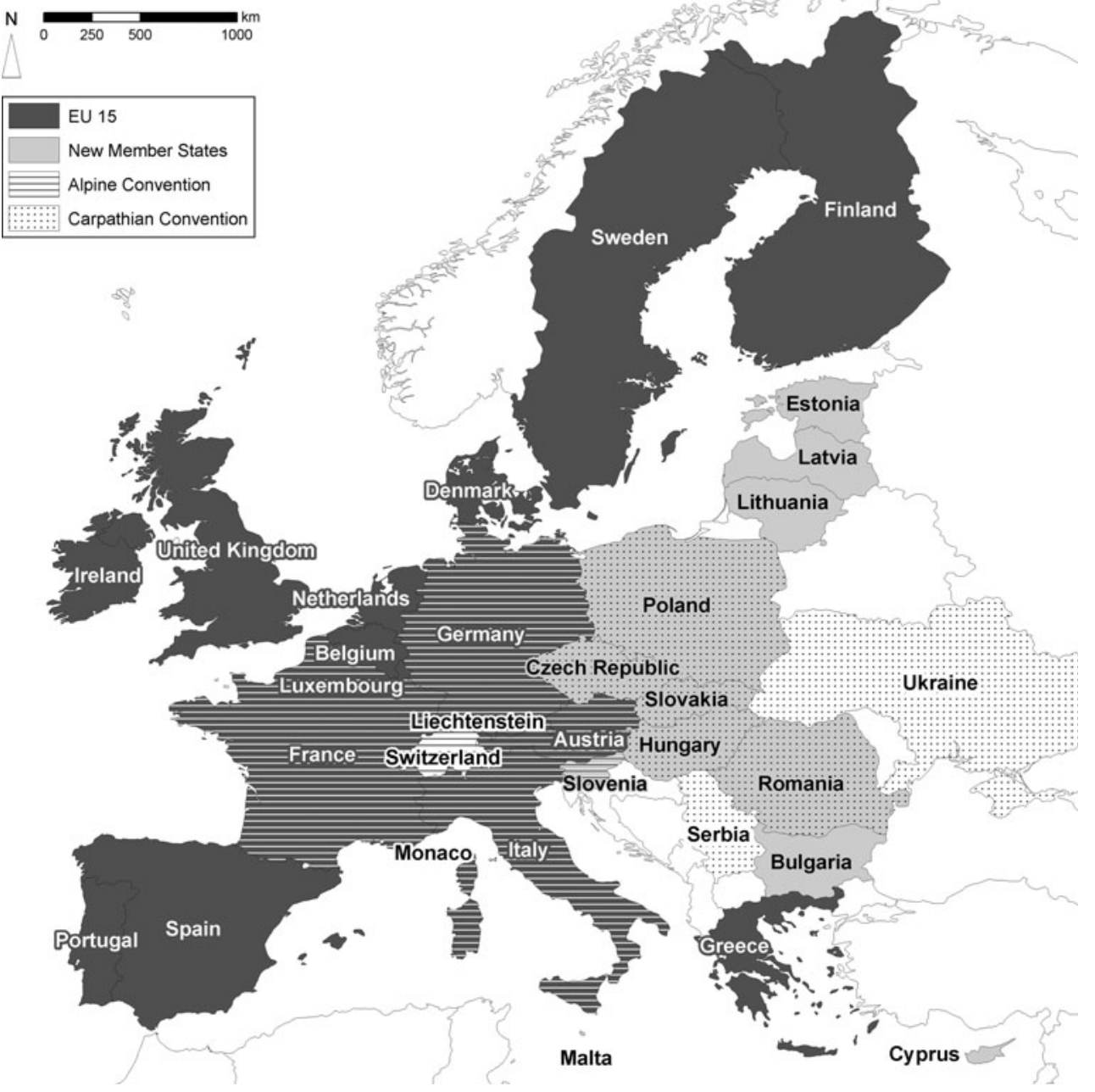
and may serve as a preliminary basis for further discussions. Below this threshold many, though certainly not all, populations of conservation-relevant species dissected by a road are thought to remain viable by several authors (e.g., Hels and Buchwald 2001; Iuell and others 2003; Seiler 2003, 2005; Jaeger and others 2006; Charry and Jones 2009).

We superimposed the GIS shape files of these lowtraffic areas with those of Natura 2000 sites in Germany (merging Special Areas of Conservation and Special Protection Areas, Federal Agency for Nature Conservation, technical data on moderately fragmented areas with low traffic intensity from 2006, unpublished) to analyze their spatial relationship. Particularly, our aim was to determine to what extent low-traffic areas are protected within the Natura 2000 network and to what extent Natura 2000 sites lie outside these areas. As the ecological coherence of the Natura 2000 network is one of the main goals of the Habitats Directive, we were also interested in determining the degree of fragmentation of Natura 2000 sites. For this purpose, we counted the number of spatially isolated subareas each Natura 2000 site is composed of and analyzed the class size distribution of subareas for Special Areas of Conservation and Special Protection Areas separately.

Although the Natura 2000 network covers an important proportion of the country (16\%; Table 2; Fig. 2), most lowtraffic areas (75\%) lie outside the network and thus remain without protection. This proportion is higher for the old Federal States (western Germany), where only one fifth of low-traffic patches are protected. The new Federal States are much less fragmented, and about $45 \%$ of its surface consists of low-traffic areas, as against $18 \%$ in the old Federal States. They also contain a relatively larger proportion of sites designated as Natura 2000. More than half of the Natura 2000 sites in Germany lie outside low-traffic areas, especially in the old Federal States (72\% of the sites; Table 2). Natura 2000 sites are highly fragmented, and often they consist of several subareas, many of which have a very small size. Almost $64 \%$ of these subareas classified as Special Areas of Conservation are less than 50 ha
(Fig. 3). In the case of the Special Protection Areas these figures are better $(27 \%)$. In general, Special Areas of Conservation comprise smaller subareas; only $4 \%$ of them cover more than 1000 ha, against $26 \%$ in the case of Special Protection Areas (Fig. 3).

\section{Discussion: Roadless and Low-Traffic Areas as a Key Element of European Conservation Policy}

Biodiversity continues to decline in Europe in spite of considerable conservation efforts carried out by administrations as well as non-governmental organisations (EC 2010). The unaccomplished target of halting biodiversity loss by 2010 (EU 2001; EC 2010) calls for additional conservation measures to be put into practice as soon. Fruit of this concern are recent initiatives of the European Commission on defining targets beyond 2010, developing "Green Infrastructures" or scaling up efforts to protect wilderness (EP 2008, 2009; EC 2011a, b). The need to strengthen the Natura 2000 network and adapt it to the rising challenges of climate change has also been highlighted. In this context, ecosystem resilience and landscape connectivity are key goals that should be reinforced (EP 2010a, b). The MACIS report (Berry and others 2008) states that to prevent and minimise future impacts of climate change on biological diversity in the EU, the minimization of fragmentation and the creation of connectors between protected areas is of extreme importance. Therefore, maintaining unfragmented large patches of natural habitats, i.e., roadless and low-traffic areas, seems a prudent strategy under any climate change scenario.

The capacity of an ecosystem to preserve its integrity and biodiversity increases in large habitats that are well connected and which are far from the influence of external disturbances (e.g., Fahrig and Merriam 1985). We feel that there is enough evidence of the benefits of roadless and low-traffic areas for nature conservation, especially in the context of global change. They represent sites with low human footprint, a high level of ecological integrity, and thus, intact ecosystem functioning and ongoing ecological

Table 2 Representation of low-traffic areas and Natura 2000 sites in Germany, with a distinction between the old and the new Federal States

\begin{tabular}{llll}
\hline & Old Federal States & New Federal States & Whole Germany \\
\hline Surface & 248,884 & 109,025 & 357,909 \\
Low-traffic areas & $45,161(18 \%)$ & $48,843(45 \%)$ & $94,004(26 \%)$ \\
Natura 2000 sites & $33,662(14 \%)$ & $23,753(22 \%)$ & $57,415(16 \%)$ \\
Low-traffic areas not covered by Natura 2000 sites & $35,677(79 \%)$ & $34,398(70 \%)$ & $70,075(75 \%)$ \\
Natura 2000 sites lying outside low-traffic areas & $24,178(72 \%)$ & $9,308(39 \%)$ & $33,486(58 \%)$ \\
\hline
\end{tabular}

The surface $\left(\mathrm{km}^{2}\right)$ and percentage of low-traffic areas, Natura 2000 sites and their overlap are also indicated. Low-traffic areas are defined as larger than $100 \mathrm{~km}^{2}$ and crossed only by small roads with less than 1000 vehicles per day (Data from 2007, BfN 2008) 


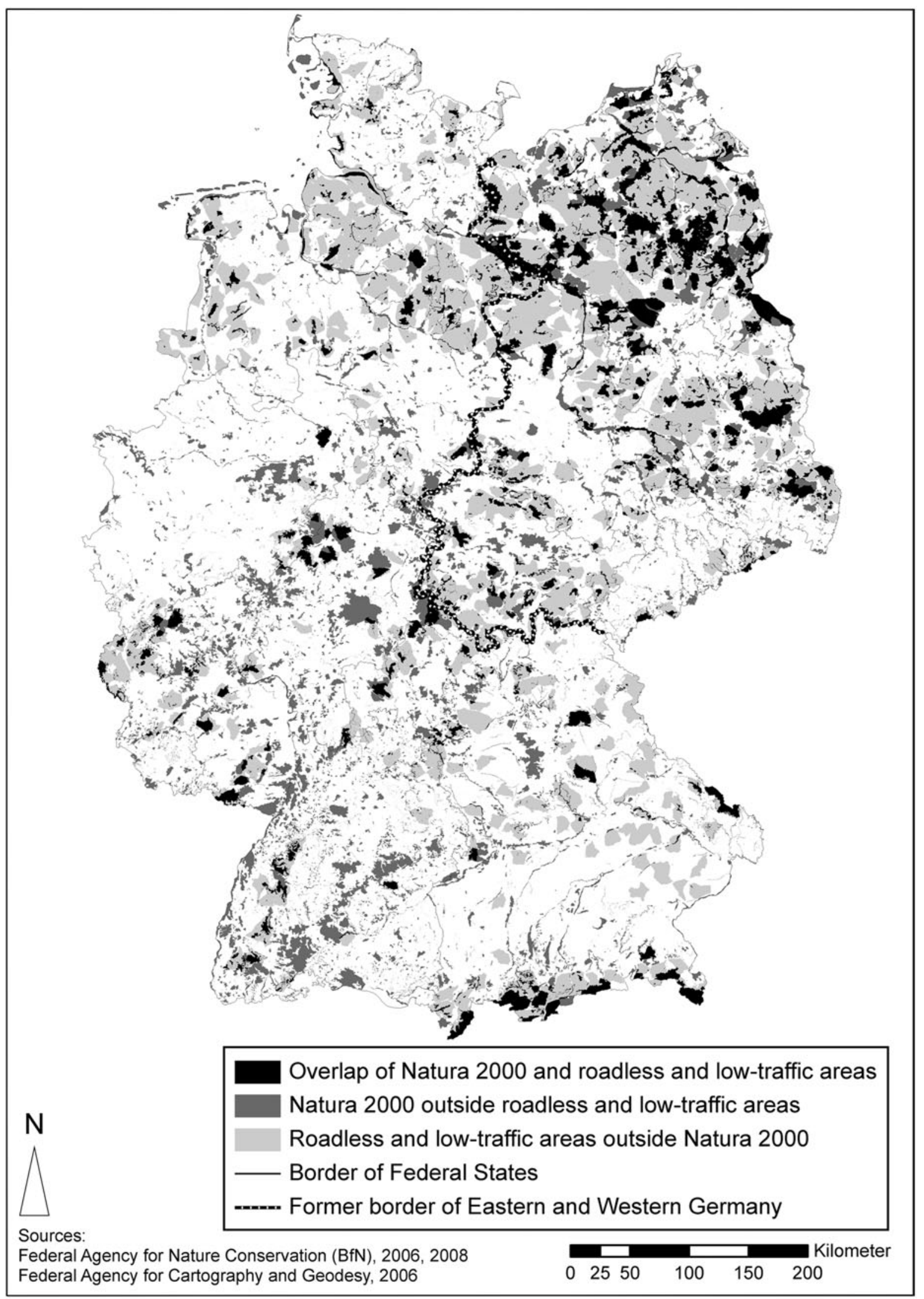

Fig. 2 Natura 2000 network and low-traffic areas coverage in Germany 
Fig. 3 Size class distribution of the subareas forming Natura 2000 sites in Germany: Special Protection Areas (Birds Directive) and Special Areas of Conservation (Habitats Directive)
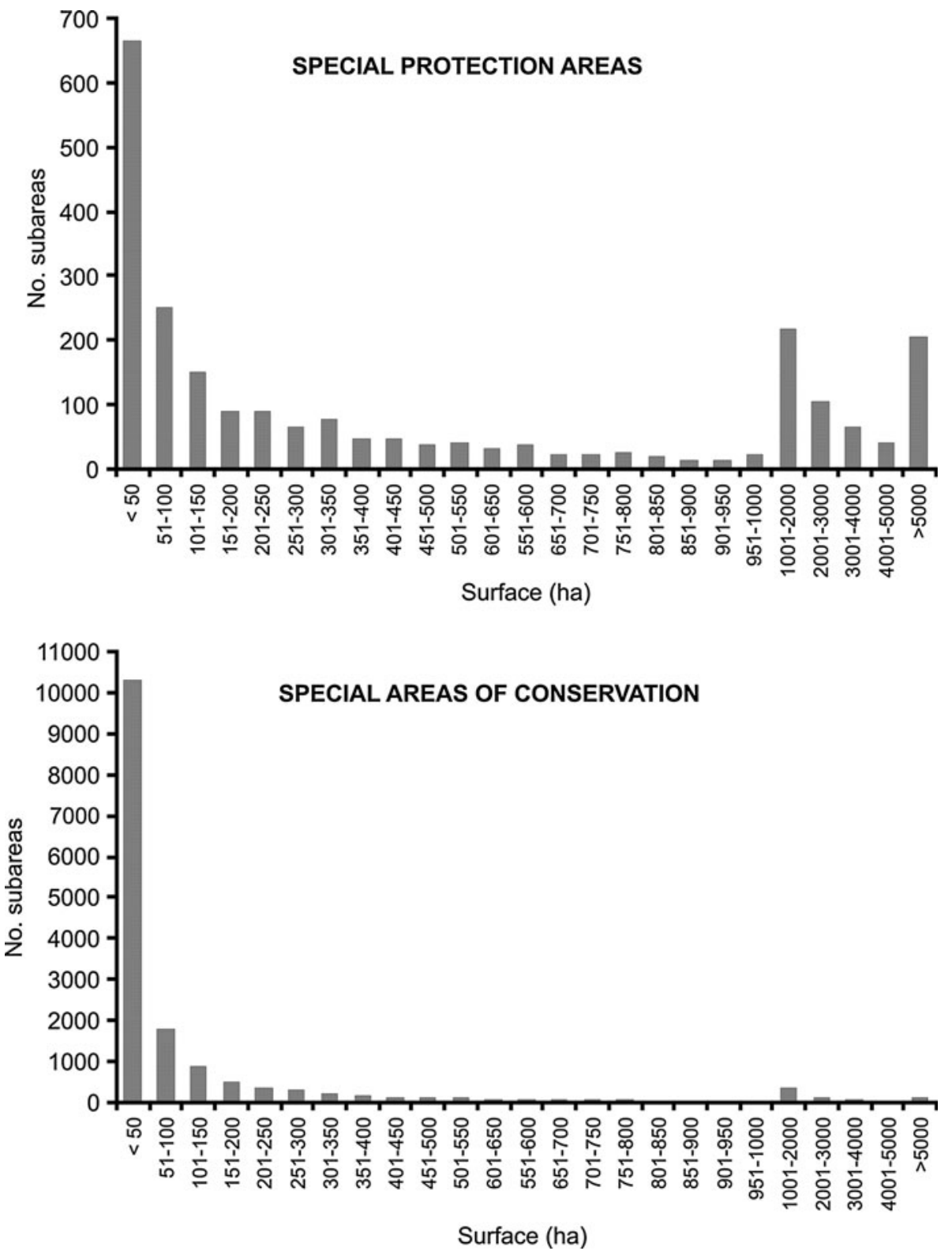

processes, which translates into higher resilience and adaptive capacity. Even in densely populated and intensively used landscapes, like Germany, the remaining roadless and low-traffic areas may be of enormous value in supporting resilience and adaptive capacity of the biodiversity. In many areas of Europe, it is probably too late to conserve roadless areas sensu stricto to a substantial extent. In this context, the last remnants are of special value, much more if they are primeval or close to a natural state. Although the importance of keeping unfragmented large patches of natural habitats is increasingly recognised (e.g., Jaeger and others 2006; Charry and Jones 2009; BenítezLópez and others 2010), more research on the ecological benefits of both roadless and low-traffic areas in Europe is deemed necessary. Such research efforts should be accompanied by improving the quality and availability of road data (e.g., across road types-unpaved roads included - or differentiating between urban and rural roads) and securing data coverage for the entire continent. Conservation policies should focus not only on tangible elements, like species or habitats, but also include surrogates (such as roadless areas) of more abstract conservation targets, like ecosystem functioning, ecological processes or ecosystem services.

The identification and inventory of the roadless and lowtraffic areas in Europe should be a top priority. A detailed inventory of these areas, based on sound and concrete criteria, and more detailed estimations of the level of fragmentation by roads in Europe shall form the basis for a proper assessment of the magnitude of the problem. Given 
the considerable impacts of minor and unpaved roads in natural ecosystems (e.g., Reed and others 1996; Riitters and Wickham 2003; van Langevelde and others 2009), fragmentation and impact assessments should also consider them. As an example, in Sweden, classically considered as one of the least fragmented countries in Europe $\left(400 \mathrm{~km}^{2}\right.$ is the average size of non-fragmented land according to EEA 2002), the figures may look quite different when forest roads are taken into account. During the last decade, the rate of road construction in Swedish forests has been approximately $1700 \mathrm{~km}$ per year, as a long-term goal of the forestry sector is to have no more than $500 \mathrm{~m}$ or $1000 \mathrm{~m}$ to the nearest road in southern and northern Sweden, respectively (Swedish Forest Agency 2008). Data on the habitat types covered by roadless and low-traffic areas and their overlap with the Natura 2000 network should be compulsory in Europe. Stronger scientific evidence on traffic and area thresholds following an ecosystem approach is needed; in general, road research needs to effectively address questions of direct management relevance and design studies that have high inferential strength, e.g. evaluating impacts before and after road construction (Gontier and others 2006; Roedenbeck and others 2007).

As a second step, inventoried roadless and low-traffic areas should be considered in European legal instruments in a more explicit way. Fortunately, European legislation has just started to take them into account. In this sense, the recent Carpathian Convention and the German Federal Conservation Act are among the most progressive legal instruments in Europe (see Table 1). The urgent need to protect large, undisturbed habitat patches in Europe is increasingly recognized also at the political level. In February 2009, the European Parliament adopted the Report on Wilderness in Europe (EP 2008, 2009) that calls on the Commission for better protection of wild areas, as a means for climate protection and maintenance of ecosystem services and biodiversity. In this context, a "roadlessness" criterion for the designation of those wild areas in Europe would be highly recommended. Another possible step would be to include roadless and low-traffic areas in the Habitats Directive, either within a new annex of functional targets complementing and facilitating the adaptation of the Natura 2000 network to climate change, or even as a new category of site. Whether a special protection category or designation of these areas is needed or not, large natural areas without roads are protected de facto. Mirroring the US legislation, the main goal would be to protect roadless and low-traffic areas from further road development, namely building new roads, increase of traffic volume on existing small roads and use of off-road vehicles. Inclusion of roadless and low-traffic areas in the national and EU Biodiversity Strategies would also be desirable.

Only after being inventoried and receiving a "legal status", roadless and low-traffic areas could be properly integrated into transport and spatial planning. The Environmental Impact Assessment (EIA, 85/337/EEC) and the Strategic Environmental Assessment Directives (SEA, 2001/42/EEC) are essential instruments to assess the impacts from transport infrastructures and for the integration of ecological issues into spatial planning; however the quality of ecological assessments is still limited (e.g., inappropriate criteria and methods, local approach, lack of integration between ecological and landscape assessments, Gontier and others 2006; Joumard and Nicolas 2010). The consideration of biodiversity in environmental assessments requires a holistic approach, i.e., to scale-up to the ecosystem level and to link local and global aspects (Gontier and others 2006; Joumard and Nicolas 2010). A concrete step towards the accomplishment of this vision will be to consider roadless and low-traffic areas in environmental assessments.

Bearing in mind the strong meaning of the term (e.g., Joumard and Nicolas 2010), a sustainable and conservation-sound planning of the European transport network should take into account the still existing roadless and lowtraffic areas. Especially in the New Member States, containing highly valuable areas but where transport networks are developing at a brisk pace, more sustainable transport policies are necessary. Research shows that, whenever possible, the design of new routes should avoid dissecting remote and roadless areas (Jaeger and others 2006; Forman 2007; Charry and Jones 2009; Benítez-López and others 2010). Studies on road animal mortality, population persistence and road configuration (Jaeger and others 2006; Charry and Jones 2009) support the "bundling traffic" concept, concluding that (1) the road network should leave areas as large as possible free from disturbances due to traffic, (2) traffic should be concentrated on highly travelled roads, and (3) when traffic cannot be combined on one road, it is better to bundle roads close together than to distribute them evenly across the landscape. Thus, in natural areas with low level of fragmentation and human footprint (e.g., crossed by small roads), the general recommendation is to prevent increases in traffic volume (Charry and Jones 2009).

When avoidance of habitat fragmentation is not possible, mitigation measures and strategies to maintain landscape connectivity, like ecological corridors, should be designed (Iuell and others 2003). Wildlife passages are among the most popular measures to reduce the barrier effect. So far, scientific evidence of their effectiveness from a genetic point of view is still needed (Corlatti and others 2009). In minor roads, traffic calming is another type of intervention used to mitigate negative impacts by reducing traffic volumes and speeds, and which has been shown to increase the persistence on animal populations in areas with a dense road network (van Langevelde and 
Jaarsma 2009). Road closure, especially in remote areas, has also been suggested as a measure to decrease fragmentation (Berry and others 2008; Charry and Jones 2009). Integrated solutions are obliged to include urban planning. Given the magnitude of urban sprawl in Europe, also affecting natural habitats (EEA 2006), an equally important goal should be to impede secondary effects along existing roads in roadless and low-traffic areas. This is of high concern in countries lacking spatial plans in most of their surface (e.g., Poland) and where roads are inevitably followed by urban development. The implementation of sustainable development schemes at large spatial scales, linking long and short terms, as well as local and global issues, would prevent the degradation of the integrity of roadless and low-traffic areas and thus, of their contribution to ecosystem and landscape resilience. Clearly, in the preservation of roadless areas and sustainable development of low-traffic areas, synergies of nature conservation and other societal goals are manifold. Just to name a few examples, traffic calming also benefits health and wellbeing (less accidents, noise and pollution), and water provision to society generally improves in volume and quality with the functionality of roadless and low-traffic areas (e.g., van Langevelde and Jaarsma 2009). Such synergies make roadless areas and low-traffic areas worth considering by a variety of stakeholders beyond the conservation community. With broader societal support, their conservation may considerably gain political momentum.

Roads have brought benefits to human societies for centuries. In the current situation of road encroachment, biodiversity crisis and global and climate change, roadless and low-traffic areas may far exceed roaded areas in the benefits provided. We call for a pan-European conservation strategy defining relatively unfragmented and low- footprint areas ("roadless and low-traffic areas") regardless of their biotic characteristics as conservation targets. Further scientific evidence on their ecological benefits and further research to answer key questions in road ecology regarding low-traffic and roadless areas under the different conditions in European countries is urgently needed. Conservation scientists and administrations should join forces to halt the loss of biodiversity in Europe, to keep healthy and resilient ecosystems and to preserve the services they provide. Preserving the last roadless and low-traffic areas in Europe is a timely post-2010 target.

Acknowledgments This paper is part of an initiative launched by the Policy Committee of the Society for Conservation Biology-Europe Section. We are indebted to our colleagues from SCB, especially P. Chylarecki, M. Dieterich, B. Livoreil, O. Nevin and A. Pullin, as well as W. Barthlott and N. Fernández for support and insightful comments to the manuscript. O. Nevin kindly checked the English. We thank the German Federal Agency for Nature Conservation (BfN) for data facilitation. We also acknowledge funding for Eberswalde
University for Sustainable Development provided by the BfN under the research project "Protected areas under climate change" (FKZ $80682270 \mathrm{~K})$ and by the German Federal Ministry of Education and Research under the project "Innovation Network Climate Change Adaptation Brandenburg Berlin-INKA BB". We very much appreciated the critical and constructive support provided by four anonymous reviewers.

Open Access This article is distributed under the terms of the Creative Commons Attribution Noncommercial License which permits any noncommercial use, distribution, and reproduction in any medium, provided the original author(s) and source are credited.

\section{References}

Allan BF, Keesing F, Ostfeld RS (2003) Effects of forest fragmentation on Lyme disease risk. Conservation Biology 17:267-272

Anděl P, Gorčicová I, Hlaváč V, Miko L, Andělová H (2005) Agency for Nature Conservation and Landscape Protection of the Czech Republic. Agency for Nature Conservation and Landscape Protection of the Czech Republic. Prague

Angelstam P, Mikusinski G, Fridman J (2004) Natural forest remnants and transport infrastructure-Does history matter for biodiversity conservation planning? Ecologica1 Bulletins 51:149-162

Balkenhol N, Waits LP (2009) Molecular road ecology: exploring the potential of genetics for investigating transportation impacts on wildlife. Molecular Ecology 18:4151-4164

Benítez-López A, Alkemade R, Verweij PA (2010) The impacts of roads and other infrastructure on mammal and bird populations: a meta-analysis. Biological Conservation 143:1307-1316

Berry P, Paterson J, Cabeza M, Dubuis A, Guisan A, Jäättelä L, Kühn I, Midgley G, Musche M, Piper J, Wilson E (2008) Mitigation measures and adaptation measures and their impacts on biodiversity. MACIS project report, Oxford. http://www.macisproject.net/MACIS-deliverable-2.2-2.3.pdf

BfN (Bundesamt für Naturschutz, Federal Agency for Nature Conservation) (2008) Nature Data 2008. BfN, Bonn

Blake S, Deem SL, Strindberg S, Maisels F, Momont L, Isia IB, Douglas-Hamilton I, Karesh WB, Kock MD (2008) Roadless wilderness area determines forest elephant movements in the Congo Basin. PLoS ONE 3:e3546

Charry B, Jones J (2009) Traffic volume as a primary road characteristic impacting wildlife: a tool for land use and transportation planning. In: Wagner PJ, Nelson D, Murray E (eds) Proceedings of the international conference on ecology and transportation. Center for Transportation and the Environment, North Carolina State University, Raleigh, NC, pp 159-172

Chen X, Roberts KA (2008) Roadless areas and biodiversity: a case study in Alabama, USA. Biodiversity and Conservation 17: 2013-2022

CIA (2008) The World Factbook: 2008. Central Intelligence Agency, Potomac Books Inc. Dulles, VA

Corlatti L, Hackländer K, Frey-Roos F (2009) Ability of wildlife overpasses to provide connectivity and prevent genetic isolation. Conservation Biology 23:548-556

Crist MR, Wilmer B, Aplet GH (2005) Assessing the value of roadless areas in a conservation reserve strategy: biodiversity and landscape connectivity in the Northern Rockies. Journal of Applied Ecology 42:181-191

DellaSala DA, Frost E (2001) An ecologically based strategy for fire and fuels management in National Forest Roadless Areas. Fire Management Today 61:12-23 
DeVelice RL, Martin JR (2001) Assessing the extent to which roadless areas complement the conservation of biological diversity. Ecological Applications 11:1008-1018

EC (European Commission) (2010) Options for an EU vision and target for biodiversity beyond 2010. Communication EC, Brussels. http://ec.europa.eu/environment/nature/biodiversity/policy/pdf/ communication_2010_0004.pdf

EC (European Commission) (2011a) Ecosystems in the wider countryside and in marine environments beyond Natura 2000. http://ec.europa.eu/environment/nature/ecosystems/index_en.htm. Accessed 17 March 2011

EC (European Commission) (2011b) Our life insurance, our natural capital: an EU biodiversity strategy to 2020. http://ec.europa.eu/ environment/nature/biodiversity/comm2006/pdf/2020/1_EN_ACT_ part1_v7\%5B1\%5D.pdf. Accessed 22 August 2011

EEA (European Environment Agency) (2002) Paving the way for EU enlargement, Environmental Issue Report No. 32 (TERM 2002). EEA, Copenhagen

EEA (European Environment Agency) (2006) Urban sprawl in Europe. The ignored challenge. EEA, Copenhagen

EEA (European Environment Agency) (2010) The European environment-state and outlook 2010: synthesis. EEA, Copenhagen

EP (European Parliament) (2008) Report on wilderness in Europe (A6-0478/2008). Committee on the Environment, Public Health and Food Safety, Strasbourg

EP (European Parliament) (2009) Resolution of 3 February 2009 on Wilderness in Europe (2008/2210(INI)). Strasbourg, France

EP (European Parliament) (2010a) Resolution of 21 September 2010 on the implementation of EU legislation aiming at the conservation of biodiversity. http://ec.europa.eu/environment/nature/ biodiversity/policy/. Accessed 17 March 2011

EP (European Parliament) (2010b) Resolution of 27 September 2010 on the EU strategic objectives for the CBD COP. http://ec. europa.eu/environment/nature/biodiversity/policy/. Accessed 17 March 2011

Epps CW, Palsbøll PJ, Wehausen JD, Roderick GK, Ramey RR II, McCullogh DR (2005) Highways block gene flow and cause a rapid decline in genetic diversity of desert bighorn sheep. Ecology Letters 8:1029-1038

EU (European Union) (2001) Presidency conclusions, Göteborg European Council, 15-16 June. http://ec.europa.eu/governance/ impact/background/docs/goteborg_concl_en.pdf

Fahrig L, Merriam G (1985) Habitat patch connectivity and population survival. Ecology 66:1762-1768

Fahrig L, Rytwinski T (2009) Effects of roads on animal abundance: an empirical review and synthesis. Ecology and Society 14:21

Ferguson C, Nelson EA, Sherman GG (2008) Turning up the heat. Global warming and the degradation of Canada's boreal forest. Greenpeace Canada, Canada

Findlay CS, Bourdages J (2000) Response time of wetland biodiversity to road construction on adjacent lands. Conservation Biology 14:86-94

Fisher I, Waliczky Z (2001) An assessment of the potential impact of the TINA network on Important Bird Areas (IBAs) in the accession countries. Final report, Birdlife International and RSPB, Sandy, Bedfordshire

Forman RTT (2000) Estimate of the area affected ecologically by the road system in the United States. Conservation Biology 14:31-35

Forman RTT (2007) Major objectives for road ecology to benefit transportation and society. In: Irwin CL, Nelson D, McDermott KP (eds) Proceedings of the international conference on ecology and transportation. Center for Transportation and the Environment, North Carolina State University, Raleigh, NC, pp 597-599

Forman RTT, Alexander LE (1998) Roads and their major ecological effects. Annual Review of Ecology and Systematics 29:207-231
Forman RTT, Deblinger RD (2000) The ecological road-effect zone of a Massachusetts (U.S.A.) suburban highway. Conservation Biology 14:36-46

Forman RT, Sperling D, Bissonette JA, Clevenger AP, Cutshall CD, Dale VH, Fahrig L, France R, Goldman CR, Heanue K, Jones JA, Swanson FJ, Turrentine T, Winter TC (2003) Road ecology: science and solutions. Island Press, Washington, $\mathrm{p} 481$

Gelbard JL, Harrison S (2003) Roadless habitats as refuge for native grasslands: interactions with soil, aspect, and grazing. Ecological Applications 13:404-415

Gontier M, Balfors B, Mörtberg U (2006) Biodiversity in environmental assessment- current practice and tools for prediction. Environmental Impact Assessment Review 26:268-286

Harmon ME, Ferrell WK, Franklin JF (1990) Effects on carbon storage of conversion of old-growth forests to young forests. Science 247:699-702

Haskell DG (2000) Effects of forest roads on macroinvertebrate soil fauna of the Southern Appalachian mountains. Conservation Biology 14:57-63

Hawbaker TJ, Radeloff VC, Clayton MK, Hammer RB, GonzálezAbraham CE (2006) Road development, housing growth, and landscape fragmentation in northern Wisconsin: 1937-1999. Ecological Applications 16:1222-1237

Hels T, Buchwald E (2001) The effect of road kills on amphibian populations. Biological Conservation 99:331-340

Holdsworth AR, Frelich LE, Reich PB (2007) Regional extent of an ecosystem engineer: earthworm invasion in northern hardwood forests. Ecological Applications 17:1666-1677

Ibisch PL, Nowicki C, Araujo N, Müller R, Reichle S (2005) Bolivia: targeting ecological processes and functionality, not the "living dead". In: Dudley N, Parrish J (eds) Closing the gap: creating ecologically representative protected area systems. CBD Technical Series 24. Secretariat of the Convention on Biological Diversity, Montreal, Canada, pp 83-84

Iuell B, Bekker GJ, Cuperus R, Dufek J, Fry G, Hicks C, Hlavác V, Keller VB, Rosell C, Sangwine T, Tørsløv N, Wandall N, le Maire B (2003) Wildlife and traffic: a European handbook for identifying conflicts and designing solutions. KNNV Publishers, Utrecht, p 176

Jaeger JAG, Fahrig L, Ewald KC (2006) Does the configuration of road networks influence the degree to which roads affect wildlife populations? In: Irwin CL, Garrett P, McDermott KP (eds) Proceedings of the international conference on ecology and transportation. Center for Transportation and the Environment, North Carolina State University, Raleigh, NC, pp 151-163

Jaeger JAG, Schwarz-von Raumer HG, Esswein H, Müller M, Schmidt-Lüttmann M (2007) Time series of landscape fragmentation caused by transportation infrastructure and urban development: a case study from Baden-Württemberg, Germany. Ecology and Society 12:22

Joumard R, Nicolas JP (2010) Transport project assessment methodology within the framework of sustainable development. Ecological Indicators 10:136-142

Keller I, Nentwig W, Largiadèr CR (2004) Recent habitat fragmentation due to roads can lead to significant genetic differentiation in an abundant flightless ground beetle. Molecular Ecology 13:2983-2994

Krieger DJ (2001) Economic value of forest ecosystem services: a review. The Wilderness Society, Washington, DC

Laurance WF, Williamson GB (2001) Positive feedbacks among forest fragmentation, drought and climate change in the Amazon. Conservation Biology 15:1529-1535

Laurance WF, Goosem M, Lauranc SGW (2009) Impacts of roads and linear clearings on tropical forests. Trends in Ecology and Evolution 12:659-669 
Loomis J, Richardson R (2000) Economic values of protecting roadless areas in the United States. The Wilderness Society, Washington, DC

Loucks C, Brown N, Loucks A, Cesareo K (2003) USDA Forest Service Roadless Areas: potential biodiversity conservation reserves. Conservation Ecology 7:art 5

Lovejoy TE (2006) Protected areas: a prism for a changing world. Trends in Ecology and Evolution 21:329-333

Luyssaert S, Schulze ED, Börner A, Knohl A, Hessenmöller D, Law BE, Ciais P, Grace J (2008) Old-growth forests as global carbon sinks. Nature 455:213-215

Markham A (1996) Potential impacts of climate change on ecosystems: a review of implications for policy-makers and conservation biologists. Climate Research 6:179-191

McGarigal K, Romme WH, Crist M, Roworth E (2001) Cumulative effects of roads and logging on landscape structure in the San Juan Mountains, Colorado (USA). Landscape Ecology 16: 327-349

Millennium Ecosystem Assessment (2005) Ecosystems and human well-being: biodiversity synthesis. World Resources Institute, Washington, DC. http://www.maweb.org/documents/document. 354.aspx.pdf

Müller K, Steinmeier C, Küchler M (2010) Urban growth along motorways in Switzerland. Landscape and Urban Planning 98:3-12

Noss RF (1991) Sustainability and wilderness. Conservation Biology 5:120-122

Noss RF (2001) Beyond Kyoto: Forest management in a time of climate change. Conservation Biology 15:578-590

Opdam P, Wascher D (2004) Climate change meets habitat fragmentation: linking landscape and biogeographical scale levels in research and conservation. Biological Conservation 117:285-297

Parmesan C (2006) Ecological and evolutionary responses to recent climate change. The Annual Review of Ecology, Evolution, and Systematics 37:637-669

Pullin AS, Báldi A, Can OE, Dieterich M, Kati V, Livoreil B, Lövei G, Mihók B, Nevin O, Selva N, Sousa-Pinto I (2009) Conservation focus on Europe: major conservation policy issues that need to be informed by conservation science. Conservation Biology 23:818-824

Reed RA, Johnson-Barnard J, Baker WL (1996) Contribution of roads to forest fragmentation in the Rocky Mountains. Conservation Biology 10:1098-1106

Reijnen R, Foppen R, ter Braak C, Thissen J (1995) The effects of car traffic on breeding bird populations in woodland. III: Reduction of density in relation to the proximity of main roads. Journal of Applied Ecology 32:187-202

Riitters KH, Wickham JD (2003) How far to the nearest road? Frontiers in Ecology and the Environment 1:125-129

Riley SPD, Pollinger JP, Sauvajot RM, York EC, Bromley C, Fuller TD, Wayne RK (2006) A southern California freeway is a physical and social barrier to gene flow in carnivores. Molecular Ecology 15:1733-1741

Roedenbeck IA, Fahrig L, Findlay CS, Houlahan JE, Jaeger JAG, Klar N, Kramer-Schadt S, van der Grift EA (2007) The Rauischholzhausen agenda for road ecology. Ecology and Society $12: 11$

Sanderson EW, Jaiteh M, Levy MA, Redford KH, Wannebo AW, Woolmer G (2002) The human footprint and the last of the wild. BioScience 52:891-904
Saunders DA, Hobbs RJ, Margules CR (1991) Biological consequences of ecosystem fragmentation: a review. Conservation Biology 5:18-32

Seiler A (2003) The toll of the automobile: wildlife and roads in Sweden. PhD thesis, Swedish University of Agricultural Sciences, Uppsala

Seiler A (2005) Predicting locations of moose-vehicle collisions in Sweden. Journal of Applied Ecology 42:371-382

Steer Davies Gleave (2009) Ex post evaluation of cohesion policy programmes 2000-2006. Work package 5A: Transport. First Intermediate Report for the European Commission. http://ec. europa.eu/transport/infrastructure/doc/2009_intermediate_report_ dg_regio.pdf. Accessed 15 March 2011

Swedish Forest Agency (2008) Statistical yearbook of forestry 2008. Official Statistics of Sweden, Swedish Forest Agency, Jönköping

Strittholt JR, DellaSala DA (2001) Importance of roadless areas in biodiversity conservation in forested ecosystems: case study of the Klamath-Siskiyou ecoregion of the United States. Conservation Biology 15:1742-1754

Theobald DM (2008) Network and accessibility methods to estimate the human use of ecosystems. In: Bernard L, Friis-Christensen A, Pundt H, Compte I (eds) Proceedings of the 11th AGILE international conference on geographic information science. University of Girona, Spain

TINA (TINA Vienna-Transport Strategies) (2008) Implementation report on the TEN-T guidelines for the period 2004-2005 (TREN/2006/ADM/S07.60719/162/B1). Final Report-Annex. http://ec.europa.eu/transport/infrastructure/studies/doc/2008_01_ ten_t_implementation_report_2004_2005.zip. Accessed 22 August 2011

Trombulak SC, Frissell CA (2000) Review of the ecological effects of roads on terrestrial and aquatic communities. Conservation Biology 14:18-30

Turner JM (2006) Conservation science and forest service policy for roadless areas. Conservation Biology 20:713-722

Turner T (2009) Roadless rules. The struggle for the last wild forests. Island Press, Washington, DC, p 192

USDA Forest Service (2000) Final environmental impact statement of the roadless conservation rule. USDA Forest Service, Washington, DC

USDA Forest Service (2001) Roadless areas conservation final rule. Federal Register 66:3244-3275

van Langevelde F, Jaarsma CF (2009) Modeling the effect of traffic calming on local animal population persistence. Ecology and Society $14: 39$

van Langevelde F, van Dooremalen C, Jaarsma CF (2009) Traffic mortality and the role of minor roads. Journal of Environmental Management 90:660-667

von der Lippe M, Kowarik I (2007) Long-distance dispersal of plants by vehicles as a driver of plant invasions. Conservation Biology 21:986-996

Walther GR, Post E, Convey P, Menzel A, Parmesan C, Beebee TCJ, Fromentin JM, Hoegh-Guldberg O, Bairlein F (2002) Ecological responses to recent climate change. Nature 416:389-395

Watkins RZ, Chen J, Pickens J, Brosofske KD (2003) Effects of forest roads on understory plants in a managed hardwood landscape. Conservation Biology 17:411-419

Wilkie D, Shaw E, Rotberg F, Morelli G, Auzel P (2000) Roads, development, and conservation in the Congo basin. Conservation Biology 14:1614-1622 